\title{
Factors Affecting Buyers Decision While Purchasing Hatchback Car
}

\author{
Dr. A. Ravi MBA, M Phil, PhD, D.Litt ${ }^{1}$, N.Priya MBA, M Phil ${ }^{2}$ \\ ${ }^{1}$ Professor \& Director, Koshys Institute of Management Studies, Bangalore \\ ${ }^{2}$ Research Scholar, Bharathiyar University, Coimbatore, India
}

\begin{abstract}
The purpose for conducting the survey is to identify the components which influencing consumers brand preference for hatchback cars in Hosur region. The analysis report shows that majority of customers in this region preference is towards Maruti Suzuki brand in hatchback models. At the time of making the purchase decision consumers considered safety, performance; aesthetic and value are the factors affecting consumer's brand preference for hatchback cars. Exploratory Factor Analysis shows safety, performance, aesthetic and value are positively influencing the consumer's overall satisfaction for hatchback cars. Therefore, hatchback car manufactures need to focus on value added activities such as consumers have better perception for the quality of brand, features and facilities. As there is a huge competitions in the market companies has to provide low price cars with best quality and less maintenance for their buyer's and also need to consider the fuel efficiency factor, as Indian consumers are considered all these factors at the time of making their purchase decision in hatchback car models.
\end{abstract}

Keywords: Buyer's Decision, Explanatory Factor Analysis, Brand Choice, Hatchback Cars, perception and behaviour.

\section{Introduction}

The automobile business sector is getting at the peak point with its numerous models of passenger cars, the situation in the market get change from the sharp difference of monopolistic business, which was at prime time till late 1980 's. From last 2 decade there was tremendous change and boom in the Automobile Industry in India, with the change in the policy done by Indian Government in economy of Liberalization and in License Raj. From mid1990 Government of India permitted foreign automobile companies to do the joint venture with Indian companies. Consequently, Government of India had also permitted Foreign Direct Investment with an equity cap in the business, which gives numerous opportunities to automobile giants to get enter in the Indian business market with their models, services, accessories, etc. with lots of benefits to their business. As there is a wonderful market opportunity available in the India, as a result of development in the increase in population and change in the living standard of common men, it shows a quick improvement in demand curve for Indian car industry. As a result of this Indian car maker become successful like never before in the past few years. A drastic and sudden zeal of major global automobile players diverted towards Indian car industry, reason as Indian automobile industry gives dual advantage of wellequipped and ready potential market and low cost of labor for manufacturing. At the same time with the drastic change in the policies of globalization and liberalization in automobile industry and produced creative, innovative and well advanced technological car models also attracter's global players in India. As companies had provided a huge range of new and innovative models in the market which made the customers to re-think their preference towards to model of car, as per their stander of living and their prestigious status in the society.

As there is a financial boom in the economy of the country and the standard of living of common men had also increase, the purchasing power of consumers gets also changed. Due to this the automobile companies attracts the customers by transforming the luxury to the necessity ingredient for the middle class families. For that automobile companies were doing tremendous efforts in the current Indian market, by providing new and innovative features, facilities, value added services, easy mode of finance, etc. which attracts the customers in this competitive market. Companies are also targeting those families those who were using two wheelers to get converted in four wheelers through cheap and low maintains cars. As, India is one of the biggest manufacturer of hatchback family cars which covers almost three-fourths of the Indian auto mobile sectors. Hatchback cars are arranged by value range which differs from 1 to 7 lakhs. It has the ability to carry max. 4 to 5 members. These are essentially basic levels cars in their entry level of their segment in Indian Market. With this background, the current study is endeavored to recognize the variables influencing customer's perception feeling towards hatchback cars in Hosur.

\section{Review Literature}

1. Dr. H. S. Adithya (2013) is conducted the study on "Customer Perception and Behaviour of car Owners - an Empirical Study in Bangalore City". To know the Value for money and satisfaction are the two important factors as per the respondents in the following study (1). In hatchback cars Brand name is one of the most popularity factors at the time of selecting any brand car (1). And $50 \%$ of the respondents are price sensitive (1) .

2. Dr. S. Subadra, Dr. K. M. Murugesan \& Dr. R. Ganapathi (2010) has conducted the study on "Consumer Perceptions and Behaviour: A Study with Special Reference to Car Owners in Namakkal District". The purpose of conducting the survey is to confirm that to make a place in the consumers mind, the manufactures need to create a position of their products through different promotional activities 


\section{International Journal of Science and Research (IJSR) \\ ISSN (Online): 2319-7064}

Index Copernicus Value (2016): 79.57 | Impact Factor (2015): 6.391

like sales promotion or through advertisement media (2). As in India the number of nuclear families are getting increase also increase in the demand of small car segment due to more parking problems in crowded areas (2). Due to which manufactures need to design the product by understand the needs, wants, tastes and preferences of consumers (2). As per the research paper it has also been identified that respondents identify the driving comfort and fuel economy are the two most important features in passenger car and also identified the spare parts and price of the car (2)

3. Shiv Prasad Joshi (2013), has conducted the study on "Consumer Behavior for Small Cars: An Empirical Study". As per the study of Shiv Prasad Joshi research paper it shows that price of the car is one of keen important factor at the time of purchase decision of cars (3). And consumers are preferring less to the safety measures in small cars (3). But manufactures also need to give a very important attention to after sales service, easy availability accessories, mileage efficiency and warranty of cars (3)

\section{Objectives of Study}

To recognize and examine the features persuading the buying of cars.

To study the various features that trigger consumers to buy specific four-wheeler brands.

\section{Research Methodology}

As to understand the behaviour of the consumer's we have conducted a pilot survey for the present study in the Hosur region. We have implemented random sampling technique to understand the behaviour of the customers those who want to purchase hatchback car. The sample data and information have been collected from 200 consumers through online structured questionnaire. In order to understand the behavior aspect of consumer for hatchback cars and the brand preference the frequency and percentage analysis have beencarried out. And to understand which key factors are influencing the consumer's for brand preference for hatchback cars, the exploratory factor analysis has been implemented.

\section{Results and Discussion}

Demographic factors to know the status of Consumers: The demographic status of consumer for hatchback car was analyzed and outcome were presented in Table-1

The outcome shows that about $67.50 \%$ of the consumers for preferring the hatchback cars are male and rest $32.50 \%$ of the consumers are female. The result also specifies that about $38.00 \%$ of the consumers of hatchback cars belong to the age group of 21-30 years followed
Table 1: Demographic factor analysis of the Consumers

\begin{tabular}{|c|c|c|}
\hline PARTICULARS & FREQUENCY & PERCENTAGE \\
\hline \multicolumn{3}{|l|}{ Age (years) } \\
\hline Up to 20 & 7 & $3.50 \%$ \\
\hline $21-30$ & 76 & $38.00 \%$ \\
\hline $31-40$ & 61 & $30.50 \%$ \\
\hline $41-50$ & 25 & $12.50 \%$ \\
\hline Above 50 & 31 & $15.50 \%$ \\
\hline \multicolumn{3}{|l|}{ Gender } \\
\hline Male & 135 & $67.50 \%$ \\
\hline female & 65 & $32.50 \%$ \\
\hline \multicolumn{3}{|c|}{ Educational Qualification } \\
\hline Higher Secondary & 14 & $7.00 \%$ \\
\hline Graduation & 65 & $32.50 \%$ \\
\hline Post Graduation & 106 & $53.00 \%$ \\
\hline Professional & 110 & $5.00 \%$ \\
\hline Others & 3 & $1.50 \%$ \\
\hline \multicolumn{3}{|l|}{ Occupation } \\
\hline Business & 38 & $19.00 \%$ \\
\hline Professionals & 49 & $24.50 \%$ \\
\hline Government & 23 & $11.50 \%$ \\
\hline Private & 49 & $24.50 \%$ \\
\hline Retired & 3 & $1.50 \%$ \\
\hline Home Maker & 23 & $11.50 \%$ \\
\hline MNCs & 5 & $2.50 \%$ \\
\hline \multicolumn{3}{|c|}{ Monthly House hold Income ( Rs) } \\
\hline Up to 25000 & 60 & $30.00 \%$ \\
\hline $25001-50000$ & 69 & $34.50 \%$ \\
\hline $50001-75000$ & 35 & 17.5 \\
\hline $75001-100000$ & 18 & $9.00 \%$ \\
\hline Above 100000 & 18 & $9.00 \%$ \\
\hline \multicolumn{3}{|l|}{ Martial status } \\
\hline Married & 60 & $30.00 \%$ \\
\hline Unmarried & 140 & $70.00 \%$ \\
\hline \multicolumn{3}{|l|}{ Family type } \\
\hline Nuclear & 102 & $51.00 \%$ \\
\hline Joint & 98 & $49.00 \%$ \\
\hline
\end{tabular}

Analysis also clearly shows that about $53 \%$ of the consumers of hatchback cars belongs to post-graduation followed by graduation (32.50\%), higher schooling (7.00\%), professional $(5.00 \%)$, formal education $(1.00 \%)$ and other educational qualification $(1.50 \%)$. It is also observed that about $24.50 \%$ of the consumers of hatchback cares were professionals and private sectors, followed by business (19.00\%), Government \& home makers (11.50\%), MNC's $(2.50 \%)$ and Retired (1.50\%).

Analysis also shows that about $34.50 \%$ of the consumers of hatchback cars belong to the monthly income group of Rs. $25,001-50,000$ followed by up to 25,000 (30.00\%), Rs. $50,001-75,000$ (17.50\%), 75,001-1,00,000 (9.00\%) and above $1,00,000(9.00 \%)$. The results also shows that about $70.00 \%$ of the consumers of hatchback cars are unmarried, while Married $(29.00 \%)$. Analysis indicates that about $51.00 \%$ of the consumers belong to nuclear family and rest $49.00 \%$ of consumers belong to joint family.

Consumer's Brand Preference for hatchback cars:

The consumer's brand preference for hatchback cars was analyzed and the results are presented in Table- 2 . 


\section{International Journal of Science and Research (IJSR)}

ISSN (Online): 2319-7064

Index Copernicus Value (2016): 79.57 | Impact Factor (2015): 6.391

\begin{tabular}{|c|c|c|}
\hline B rand & Frequency & Percentage \\
\hline Maruti Suzuki 1 & 109 & $54.50 \%$ \\
\hline Hyundai & 36 & $18.00 \%$ \\
\hline Ford & 2 & $2.00 \%$ \\
\hline Nissan & 3 & $1.50 \%$ \\
\hline Tata & 7 & $3.50 \%$ \\
\hline Volkswagen & 6 & $3.00 \%$ \\
\hline Honda & 19 & $9.50 \%$ \\
\hline Chevrolet & 2 & $1.00 \%$ \\
\hline Toyota & 4 & $2.00 \%$ \\
\hline Skoda & 5 & $2.50 \%$ \\
\hline Others & 7 & $3.50 \%$ \\
\hline total & 200 & $100 \%$ \\
\hline
\end{tabular}

The analysis show that about $54.50 \%$ of consumers prefer Maruti Suzuki brand of hatchback cars followed by Hyundai (18.00\%), Honda (9.50\%), TATA (3.50\%), Volkswagen (3.00\%), Skoda (2.50\%), Ford \& Toyota $(2.00 \%)$, Nissan (1.50\%), Chevrolet(1.00\% per cent) and others (3.50\%).

\section{Factors Affecting Consumer's Brand Preference of Small}

\section{Cars}

Kaiser-Meyer-Olkin Measure of sampling adequacy is computed as 0.798 for these statements. The overall significance of correlation matrices is tested with Bartlett Test of Sphericity. Statements Adopted in the study as well as support for the validity of the factor analysis of the data set.

Bartlett's test was used to test the null hypothesis that the variables of this study are not correlated. Since the appropriate chi-square value is 2322.763 which are significant at $5 \%$ level, the test leads to the rejection of the null hypothesis and confirmed that the statements are correlated and hence Factor Analysis applied.

\section{$\underline{\text { Results of KMO and Bartlett's Test }}$}

\begin{tabular}{|c|l|r|}
\hline $\begin{array}{c}\text { Kaiser-Meyer-Olkin Measure of } \\
\text { Sampling Adequacy. }\end{array}$ & 0.905 \\
\hline \multirow{3}{*}{$\begin{array}{c}\text { Bartlett's Test of } \\
\text { Sphericity }\end{array}$} & $\begin{array}{l}\text { Approx. } \\
\text { Chi-Square }\end{array}$ & 3064.24 \\
\cline { 2 - 3 } & Df & 351 \\
\cline { 2 - 3 } & Sig. & 0.000 \\
\hline
\end{tabular}

Factors Affecting Consumer's Brand Preference towards hatchback cars

Exploratory Factor Analysis

\begin{tabular}{|c|c|c|c|c|c|}
\hline \multicolumn{6}{|c|}{ Rotated Component Matrix } \\
\hline & \multicolumn{5}{|c|}{ Component } \\
\hline & 1 & 2 & 3 & 4 & 5 \\
\hline [Exterior Design (Look \& Style) & .153 & .045 & .742 & .044 & .095 \\
\hline Leg Spacing & .252 & .664 & .271 & .067 & -.086 \\
\hline Dash Board \& Interior Design & .345 & .077 & .705 & .119 & .091 \\
\hline Music System & .454 & .167 & .424 & .138 & .333 \\
\hline Mileage (Fuel Consumption) & .124 & .717 & .099 & .344 & -.192 \\
\hline Pick Up & .701 & .204 & .118 & .185 & -.006 \\
\hline Top Speed & .720 & .002 & .226 & .279 & -.093 \\
\hline Seats comfort & .336 & .546 & .454 & .029 & .040 \\
\hline Boot Space capacity & .409 & .571 & .229 & .256 & .048 \\
\hline Air-conditioning & .265 & .272 & .644 & .252 & -.162 \\
\hline Air Bagi & 721 & 368 & 074 & 127 & 061 \\
\hline Anti-Lock Braking System & 614 & 461 & 194 & .034 & 099 \\
\hline Suspension quality & 469 & 458 & 449 & -101 & 140 \\
\hline Tubeless Radial Tyres & 471 & 280 & 437 & 097 & 211 \\
\hline Key \& lock Features & 605 & 218 & 333 & 142 & 329 \\
\hline Rear Parking Camera & 679 & -.006 & 365 & 140 & 261 \\
\hline Door \& Window Features & 457 & 015 & $\$ 24$ & .233 & .318 \\
\hline Dealers Offer & 092 & 281 & 089 & 734 & -.080 \\
\hline Status in the society & .314 & -121 & .257 & .702 & 164 \\
\hline After Sales Service & -198 & 440 & .365 & 258 & 413 \\
\hline Finance Availability & 165 & 218 & -094 & 683 & 191 \\
\hline Resale Value & -019 & 384 & 148 & 731 & 023 \\
\hline Brand Name & 270 & 056 & 188 & 639 & 223 \\
\hline Price of car & .208 & 663 & -178 & 259 & 308 \\
\hline Range of Colors & 381 & 149 & 178 & 254 & 663 \\
\hline Repairing \& Maintains Cost & 121 & 800 & -018 & 140 & .266 \\
\hline $\begin{array}{l}\text { Type of Engine (Petrol, Diesel \& } \\
\text { Gas) }\end{array}$ & .022 & .501 & .401 & .188 & .295 \\
\hline
\end{tabular}

Volume 6 Issue 12, December 2017 www.ijsr.net 
International Journal of Science and Research (IJSR)

ISSN (Online): 2319-7064

Index Copernicus Value (2016): 79.57 | Impact Factor (2015): 6.391

\begin{tabular}{|c|c|c|c|c|c|}
\hline Factor & Items & $\begin{array}{l}\text { Rotated } \\
\text { Component } \\
\text { Matrix }\end{array}$ & $\begin{array}{l}\text { Eigen } \\
\text { Values }\end{array}$ & $\begin{array}{l}\% \text { of } \\
\text { Variance }\end{array}$ & $\begin{array}{l}\text { Factor } \\
\text { Name }\end{array}$ \\
\hline \multirow{9}{*}{1} & Music System & 0.454 & \multirow{9}{*}{10.405} & \multirow{9}{*}{17.086} & \multirow{9}{*}{$\begin{array}{l}\text { Safety } \\
\text { Factor }\end{array}$} \\
\hline & Pick Up & 0.701 & & & \\
\hline & Top Speed & 0.72 & & & \\
\hline & Air Bags & 0.721 & & & \\
\hline & Anti-Lock Braking System & 0.614 & & & \\
\hline & Suspension quality & 0.469 & & & \\
\hline & Tubeless Radial Tires & 0.471 & & & \\
\hline & Key \& lock Features & 0.605 & & & \\
\hline & Rear Parking Camera & 0.679 & & & \\
\hline \multirow{8}{*}{2} & Leg Spacing & 0.664 & \multirow{8}{*}{2.486} & \multirow{8}{*}{15.75} & \multirow{8}{*}{$\begin{array}{l}\text { Performance } \\
\text { Factor }\end{array}$} \\
\hline & Mileage (Fuel Consumption) & 0.717 & & & \\
\hline & Seats comfort & 0.546 & & & \\
\hline & Boot Space capacity & 0.571 & & & \\
\hline & After Sales Service & 0.44 & & & \\
\hline & Price of car & 0.663 & & & \\
\hline & Repairing \& Maintains Cost & 0.8 & & & \\
\hline & Type of Engine (Petrol, Diesel \& Gas) & 0.501 & & & \\
\hline \multirow{4}{*}{3} & Exterior Design (Look \& Style) & 0.742 & \multirow{4}{*}{1.893} & \multirow{4}{*}{12.966} & \multirow{4}{*}{$\begin{array}{l}\text { Aesthetic } \\
\text { Factor }\end{array}$} \\
\hline & Dash Board \& Interior Design & 0.705 & & & \\
\hline & Air-conditioning & 0.644 & & & \\
\hline & Door \& Window Features & 0.524 & & & \\
\hline \multirow{5}{*}{4} & Dealers Offer & 0.734 & \multirow{5}{*}{1.347} & \multirow{5}{*}{11.948} & \multirow{5}{*}{ Value Factor } \\
\hline & Status in the society & 0.702 & & & \\
\hline & Finance Availability & 0.683 & & & \\
\hline & Resale Value & 0.731 & & & \\
\hline & Brand Name & 0.639 & & & \\
\hline \multirow[t]{2}{*}{5} & Range of Colors & 0.663 & 1.01 & 5.736 & $\begin{array}{l}\text { Choice } \\
\text { Factor }\end{array}$ \\
\hline & Cumulative $\%$ of Variation & & & 63.486 & \\
\hline
\end{tabular}

- Rotation Method: Varimax with Kaiser Normalization.

- Extraction Method: Principal Component Analysis.

-Rotation converged in 8 iterations.

The overall percent of variance is 63.486 indicating that each measure demonstrates acceptable internal consistency. It is incidental that safety, performance, aesthetic, value, and choice are the factors affecting consumer's brand preference for hatchback cars.

\section{Conclusion}

From the above analysis it is seems that most of the customers for purchasing hatchback cars were males and major of them were belongs to the age group of 21-30 \& 31 to 40 years. Analysis also shows that more form profession and privet sectors consumers preferring hatchback cars and major are post-graduate people. Study shows that nuclear family consumers are preferring more hatchback cars and whose household monthly income is between Rs. 25001 to 50,000 .

Research study shows that majority of the consumer incline toward Maruti Suzuki brand in hatchback car models. As in current automobile sector consumer give more preference to safety, performance, aesthetic, and Value factors more now a days at the time of making their purchase decision. Rotated Component Matrix analysis shows that that safety, performance, aesthetic, and value are positively influencing the consumer's for their decision and also gives overall satisfaction to the hatchback car purchaser's. In today's fast competitive era consumers taste, choice and preference get change and therefore, the hatchback car manufacturers need to focus more on safety, performance, aesthetic and valuecreating factors so that consumers will have a better awareness of quality of the brand. As in today's automobile market there is cut throat competitions is going on price, better quality and low cost product too. As Indians consumers are more conscious about the price and fuel efficiency. So it is better for the manufactures to selling lowpriced, fuel-efficient and less maintenance cost hatchback cars to get succeed at large volumes of sales. Hence, the hatchback car manufacturers need to concentrate more on all these factors during their production and marketing plans.

\section{References}

[1] Dr. H. S. Adithya, On Customer Perception and Behavior of car Owners - an Empirical Study in Bangalore City. Global Research Analysis, Volume: 2 Issue: 1 Jan 2013, 2277 - 8160.

[2] Shailesh K. Kaushal, On Confirmatory factor analysis: An empirical study of the four- wheeler car buyer's purchasing behaviour. International Journal on Global Business Management and Research, Volume 2; Issue 2; March 2014, 22788425

\title{
Volume 6 Issue 12, December 2017
}

\author{
www.ijsr.net
}

Licensed Under Creative Commons Attribution CC BY 


\section{International Journal of Science and Research (IJSR) \\ ISSN (Online): 2319-7064}

Index Copernicus Value (2016): 79.57 | Impact Factor (2015): 6.391

[3] Shiv Prasad Joshi, On Consumer Behaviour for Small Cars: An Empirical Study. International Monthly Refereed Journal of Research in Management \& Technology, Volume II, February, 2013, 2320-0073.

[4] Ramesh Sardar(2012), "Brand Preference of Passenger Cars in Aurangabad District", International Journal of Multidisciplinary Research, 2(3): pp.431-442.

[5] Dr. S. Subadra, Dr. K. M. Murugesan, Dr. R. Ganapathi, On Consumer Perceptions and Behaviour: A Study with special reference to car owners in Namakkal District. Sri Krishna International Research \& Educational Consortium, Volume 1, Issue 3 (December, 2010), 2229-4104.

[6] Guiles M.G (2008), "Fuel Economy takes a hack seat as cars get faster and more fun", Wall Street Journal, October p.33.

[7] Ashok J., „A Study on Developing Strategies to improve the sales of Maruti Zen Passenger carse, International Journal of Management Science, Vol.1, No.1, July 2005, p.24.

[8] Baumgartner, G and Jolibert, A (2008), "Consumer Attitudes Towards Foreign Cars", International Business Studies II (spring), pp.71 - 80.

[9] Saxena R.P., Abidi N. and Malik A (2000), Consumer behaviour: Reference Group as a determinant, Productivity, 41(3), 478-483.

[10] Madikonda Kishore Babu and Raghunatha Raddy, D., A Study on Passenger Car Industry in India', Indian Jouranl of Marketing, Vol. 34, No. 10, Oct 2004.

[11] Chaudhuri, Arjun \& Holbrook, Morris B. (2001), The Chain of Effects from Brand Trust and Brand Affect to Brand Performance: The Role of Brand Loyalty, Journal of Marketing, Vol. 65 No. 2, pp. 81-93.

[12] M.Prasanna Mohan Raj, Jishnu Sasikumar, S.Sriram , A Study of Customers Brand Preference in SUVS and MUVS: Effect on Marketing Mix Variables, International Referred Research Journal Vol.- IV, Issue1, pp. 48-58, Jan 2013.

[13] Nikhil Monga, Bhuvender Chaudhary, Car Market and Buying behavior - A study on Consumer Perception, IJRMEC Vol.2, Issue-2, pp. 44-63, Feb 2012.

[14] Aaker, David. (1991). - Managing Brand Equity: Capitalizing on the Value of a Brand Namell. The Free Press, Simon and Schuster, Inc.

[15] Gaedebe R (2007), -Consumer Attitude Toward s Cars made in Developing Countrioes\|, Journal of Retailing, 49, (summer), pp13-24 